\title{
Public Procurement in Albania, Germany, Macedonia and Kosovo
}

\author{
Ervin Salianji
}

\begin{abstract}
The public procurements is a developed field in the countries which had blooming economic development trends. It is a very important field for the governments as every government is a buyer of goods, services and performance of works. During the last years in all the countries public procurement occupied an important space as through it the expenses of public money is performed. This trend of development during this period is more emphasized especially in the countries which had a transition from the planned economics to market economy ${ }^{1}$. For the eastern and central Europe public procurement these last 20 years was a new term as the economy of these countries was planned and centralized.
\end{abstract}

Keywords: Public Procurement Albania, Germany, Macedonia Kosovo

\section{Introduction}

\section{Albania}

\section{National Legislation Approach on Public Procurement}

Being that public procurement is a great political and public debate, the legislation of public procurement has continuously been changed amending the legislation in effect. In 2006 the old legislation which entered into effect in 1995 was repealed and it was amended for so many times so that it appeared as a new law in accordance to the acts of European Union. Even though 10 years passed from the approved law, this law has been changed for so many times impacting its fundamental provisions.

\subsection{Law no. 9643, on 20.11.2006, "On Public Procurement"}

The law no. 9643, on20.11.2006, "Public Procurement", as amended, is the basic law on the performance of the procurement procedures in Albania. This law was compiled in the frame of membership of Albania in the European Union, where our country has, among others, the obligation to approach the legislation on public procurement with the European Union one. The obligation to fully approach the Albanian legislation on procurement with the respective directive lies in time. Therefore being that this model came from a template UNICITRAL, it was decided that the transformation of the directive would not be immediate as the contracting authorities and economic operators would have difficulties in adjustment. From the other hand, the directive left spaces to the decision- making institutions, contracting authorities, which could create abuses in conditions of Albania. Therefore it was decided for an escalated approach of the directive in the Albanian legislation. The purpose of this law as provided in its article 1 is a) to increase efficiency in the procedures of public procurement, performed by the contracting authorities; $b$ ) to provide the good use of public funds and to decrease the procedural expenses; $c$ ) to promote the participation of economic operators in the procedures of public procurement d) to promote concurrence between economic operators e) to provide for an equal and non- discriminative treatment for all the participants in the procedures of public procurement $\mathrm{f}$ ) to provide for integrity, public trust and transparency in the procedures of public procurement, through electronic manner of procedures.

Starting from 2009, the procedures of public procurement in Albania is performed electronically through the electronic system of procurements. This laws defines the principles of public procurement, which will be explained, pursuant which the selection of winners of public contracts is performed by non- discriminating and treating in an equal manner all the bidders or candidates. Transparency in the procedures of procurement and equal treatment of requests and obligations

\footnotetext{
1 Thai V. Khi, Advancing Public Procurement: Practices, Innovation and Knowledge Sharing PrAcademics Press Boca Raton, Florida, USA
} 
are the core of public procurement procedures. The law defines the organization of public procurement dividing the role of institutions: policies maker concretely the Agency of Public Procurement; quasi judgment based on the requests from economic operator- Public Procurement Commission and the notions on the two main entities in procurement, the contracting authority and economic operators. The law presents a clear view on how the procedures of public procurements are developed, how many types of procedures are there and the cases when they can be valid. Also the law sanctions the winner's selection procedure until the signature of the contract.

\subsection{Decision of Council of Ministers No. 914, on 29.12.2014 "On the approval of the public procurement rules"}

This decision repealed the existing Decision of the Minister Council. At the second chapter "General Rules of Procurement" there are defined the monetary boundaries where: a) the high monetary boundary -1.200 .000 .000 (one billion two million) ALL for contracts on public works. At the third chapter there are defined all the Tender Standard Documents (hereinafter TSD) from the invitation on bids, winners' signature forms, complaints etc. The fourth chapter explains in details the frame agreement which is a necessity to perform tenders with continuity as characteristic (such as airplanes tickets for the authorities). The following chapters treat all the procurement procedure phases from the issuance of the order from the Representative of the Contracting Authority to the signature of the winning bid. The disciplinary measures for every violation and the relevant penalties constitute a special chapter.

\subsection{DCM No.918, on 29.12.2014 "On the performance of the public procurement procedures electronically".}

Since 2009 the public procurement procedures were performed electronically. Through the DCM no. 45 on $21^{\text {st January }}$ 2009, of the Council of Ministers "On the performance of the public procurement procedures electronically" all the procedures of public procurement would be performed online except the procurements with a small value. In 2013 through an amendment of this DCM it was decided that also the procurements with a small value would be performed through the electronic procurement, except the cases of emergent purchases under $10.000 \mathrm{ALL}$

The current decision defines that all the procurement procedures are developed through electronic means except:

a) procurement procedure "negotiation without preliminary announcement of the contract";

b)second phase of procurement procedures "consultancy service" and "Design competition";

c) procedures of procurement for a small value under 100000 (one hundred thousand) ALL which are also developed in emergent cases;

c) procurement procedures with the object "Purchase of electric power"

Part of public procurement procedures are also the guidance extracted from the Agency of Public procurement as well as Tender Standard Documents 1 .

\section{Agency of Public Procurement. It policy making and monitoring role.}

The Agency of Public Procurement if a central body, public legal person depending from the prime minister and financed by the State Budged. Its main duties as policy making body is to present to the Council of Ministers propositions on the rules of procurement. It has the duty to promote and organize the qualification of employees of central and local governance involved in the public procurement. One of the duties that public procurement legislation attributes to this institution is the compilation and publication of Public Announcements Bulletin. The Agency of Public Procurement announced in the Public Announcements Bulletin the list of excluded economic operators. It compiles pursuant the Rules of public procurement the tender standard documents to be used in the procurement procedures. According to the request from the contracted authorities which undertake a procurement procedure it gives advices and technical assistance. This agency is entitled to monitor the law implementation and in cases it ascertains violations it decided on penalties or proposes to the directors of the contractor authority or higher instance bodies disciplinary measures for the persons which have committed violations. Also the Agency of Public Procurement when found in front of the cases provided by PPL, excludes an economic operator from participating in the procurement procedures, despite the penal case for a period from 1 to 3 years ${ }^{2}$.

1 DCM No.918, on 29.12.2014 "On the performance of the public procurement procedures electronically".

2 Law no. 9643, on 20.11.2006, "On Public Procurement" 


\section{Public Procurement Commission}

The Law on Public Procurement, defines the construction and functioning of the Public Procurement Commission. Article $18 / 1$ defines that Public Procurement Commission is the highest body in the procurement field which reviews the complaints on procurement procedures, pursuant the requests defined in the PPL. The Public Procurement Commission, at the termination of complaints review makes decisions which are administratively final.

\section{The Central Purchasing Body}

When more than one contracting authority need the same goods, works or services they make decision such as a) they may appoint to one of them the duty of procurement of these goods, services of works on behalf of the thirds b) guide the central purchasing body created in accordance to the procurement rules, to perform the relevant selection procedures of selection of the contract winner. The Central Purchasing Body is now created designated as "General Directorate of Concentrated Purchase", as a directorate at the Ministry of Interior.

\section{Differences between the European Directives and domestic legislation in foreseeing procedures.}

The procedures of public procurement foreseen from PPL, were taken from the relevant directives on procurement. But it must be emphasized that there are some amendments related to some of these procedures. So for example, the limited procedure is provided from the LPP also from the directive, but the cases of using this procedure are different.

$\checkmark$ Pursuant PPL this procedure may be used only if certain conditions are met, while pursuant the Directive this procedure may be used in all the cases judged from CA, same as the open procedure.

$\checkmark$ The other difference has to do with the procedure of Consultancy Service, which pursuant the Albanian legislation is foreseen as a special procedure, while pursuant the directive, there is no such procedure, but this contract object is treated same as all the other services. From the other hand LPP does not provide the procedure of Competitive Dialogue, which is provided from the Directive as a special procedure.

\section{Germany}

Public procurement includes the sector which the governmental agencies act as contracting entities for their works and services. With a volume of $17 \%$ of gross product of Germany, the sector of public procurement has a great importance for the economy. Referring to the above information it must be emphasized that in the tender procedures the principles of transparency, concurrence and peer treatment are applied ${ }^{1}$. The Law of procurement in every of its phase aims to assure the application in an economic manner of public resources, to avoid the wrongful application and corruption and to prevent private companies from concentrating public procurements. The value of contracts in the German public sector is about 300 billion dollars per year, giving to the public procurement the potential to be in high position.

The procurements field summarizes laws, international agreements sublegal acts several acts adopted by the European Union institutions. The law of public procurement has its roots in the national system and the European one. During the last years, the laws of European Union are made more important. above all the Directives of Procurement have a significant impact in the procurement sector in Germany. The legal structure of German public procurement is compounded by the Directive 2004/18/EC, Directive 2004/17/EC, Directive 2009/81/EC, the provisions of which were implemented in the Law against limitations of competences ${ }^{2}$. This law paid a great importance to the development of small companies and medium ones, as it is very important that these companies have access at the public notifications in order to enter into contracts in the field of public procurement ${ }^{3}$. It is foreseen the possibility to form the bidders association. Specific conditions were provided for the companies which perform different inventions.

\footnotetext{
${ }^{1}$ Martin Burgi, Public procurement Law in the Federal Republik of Germany, lus Publicum, nr.2/2012, fq.1. http://www.iuspublicum.com/repository/uploads/09_02_2012_9_43_Burgi.pdf

2 Fabry B., Meininger F.,Kayser K, Vergaberecht in der Unternehmenspraxis, Ëiesbaden, 2007, page 13.

${ }^{3}$ Fostering Innovation through public procurement, http://www.bmwi.de/EN/Topics/Technology/Strong-policy-frameëork/fosteringinnovation-through-public-procurement.html
} 
The German lawmaker in accordance to the European directives as well has set monetary limits to certain sectors that which is the amount to perform public procurements in accordance with the European directives. We can mention as examples: works related to water supply, energy starting from 414,000 euro, contracts of services starting from 193,000 euro, contracts in construction starting from 4.850,000 euro. If in the mentioned areas the value of the contract is lower than the amounts reflected above the obligation to perform the notification of the tender will be considered as according to the law only if made in Germany. These directives set the criteria of the value on public procurement and in a direct manner they set for the applicable law the winner of public contract. If the value of the contract is equal or more than that the amount appointed at the directive on the limit set for the public procurement therefore the contract must be advertised in all Europe. The fundamental rules and basic principles of public procurement are: concurrence, transparency, peer treatment, economic efficiency, competence and ability of the bidder, right of bidder to be according the rules of public procurement, consideration of medium competences ${ }^{1}$.

The different legal acts of procurements are divided from the doctrine in three categories: The first subcategory there are acts related to the budged and concurrence, the second category there are decisions related to the procurements and at the last category there different guidance which contain the most important procedural provisions for the contracting body of public work sand services. The regulations are not approved by the legislative authorities and therefore there must not be considered as laws pursuant the German legal system. The regulations were created by committees of public procuration, The specific character of public procurements is the fact that the price is known as the acceptance of an offer. Actually no rules of public procurement are applied to the price, but only rules of ordinary civil law. The most important conditions are related to the selection of winning conditions. The contracts given to the operators which are suitable for the object of the contract. The bidder is considered as reliable if he has technical and efficient knowledge. The tender will be won by the person who submits the most useful offer, the price is not a determinant factor, but it is the most important factor to select the most economically favorable offer ${ }^{2}$. Pursuant the law of German public procurement, the efficiency is the most important criteria to perform all the purchases. The maximal efficiency will be the determinant criteria to win a contract and not only the lowest price. The procedure of procurement may be completely performed electronically through the modern means of information and communication. The public buyer must allow that the offer is submitted not only via mail but also via email. In this case the public byer must specify in the notification or in the tender development documents that the offer is possible to be realized in electronic way as well. When the electronic offers are accepted it must be warrantied that it content is not made public until the time of offers submission terminates.

Kosovo.

For the first time in Kosovo the notion of public procurement appeared after the war of 1999. In Kosovo the first document which regulated the field of public procurement was extracted by the Administration of United Nations in Kosovo on $15^{\text {th }}$ December 1999 known as the Instruction of Financial Administration no. 2/1999 on Public procurement. It was based on the procurements rules of World Bank and Law on International Trade of United National "UNCITRAL". While the law on public procurement in Kosovo entered into effect on $9^{\text {th }}$ June 2004, which was based in the Directives of EU on this matter. The highest body of public procurement is the Regulative Body of Public Procurement, which prepared and publishes all the documents of procurements procedures, makes the interpretation of legal provisions of this field as well as reviews the complaints of economic operators. Also another body which acts in this filed is the central unit of procurements which approves the deviations from normal procedures of procurement.

Their functioning will be explained at the following

\subsection{Legal framework of procuration}

The fundamental legislation of public procurements in Kosovo was prepared by the Mission of United Nations in Kosove "UNMIK" on $15^{\text {th }}$ December 1999 known as the Administrative Financial Guidance (UAF") No. 2/1999 on public procurements using the Consolidated Budged of Kosovo. With the Financial Administrative Guidance No.1 these two instruments set the base of public procurement in Kosovo. UAF is based in the Template Law of Procurement UNCITRAL 22 and then on the Guidance of World Bank on Procurements and Consultants. Initially This guidance was thought to be

\footnotetext{
${ }^{1}$ Khi V. Thai, Handbook of Public Procurement, CRC Press, Nju Jork, 2009, page 313.

2 Martin Burgi, Public procurement Laë in the Federal Republik of Germany, lus Publicum, nr.2/2012, page.3. http://ëëë.iuspublicum.com/repository/uploads/09_02_2012_9_43_Burgi.pdf
} 
a temporary legislative frame but it remained in effect for more than four years until 9 June 2004, a time when the Law No. 2003/17 entered into force. This law was prepared based on the Directives of Procurements of EU and it was amended in a considerable manner compared to the changes and modifications of the Law No. 02/L99, until the convention approved a completely new law on $30^{\text {th }}$ September 2010, which entered into force on $1^{\text {st }}$ December $2010^{1}$.

Pursuant the Progress Report of EU on Kosovo the law contained a number of provisions which deviated in a considerable manner from the directives of public procurement and which exposed the officials of public procurement to the political interference and pressure destroying the transparency and creating possibilities for corruption. Therefore, The government of Kosovo, was engaged to compile the amendment of the law in order to treat gabs which made this law to be different from the directives of procurement of EU. The amendments were approved by the Parliament through the law No. 04/L042 on $29^{\text {th }}$ August 2011. THE new law was published at the Official Gazette on $19^{\text {th }}$ September 2011 and entered into force after 15 days. The law of Kosovo on Public Procurement since the first approval in 2003 was amended eight times until February 2016. These continuous amendments in the legislation made its application difficult for the officials of procurement and monitors of civil society, media and citizens. The procurements system in Kosovo is highly decentralized what makes the cost bigger due to the big number of contracts between parties ${ }^{2}$. The bodies involved at the procurements process are : Regulative Commission of Public Procurement, Review Body of Procurement, Central Agency of Procurement and over 170 contracting authorities. TO make the economization of the procurement process, the law maker in Kosovo upon the latest legislative changes in 2016 at the article 21/A performed a type of concentration of public procurement which some small institutions do not deal with public procurement. The article 21/A provides that "For purposes of economization of the activities of procurement, The Government of the Republic of Kosovo and relevant Ministries perform the procedures of procurements of Agencies which respond to the,, which have less than 50 employees 2) For the independent agencies which respond to the Convention of the Republic of Kosovo, which have less than 50 employees, the procedures of procurements are performed by the Central Agency of Procuration"3.

\section{Macedonia}

In 2-14 it was created a body called "The council of Public Procurement" which is an unique body in the application of public procurement procedures in Balkan. It is under the competence of government and not under the competence of the Bureau of Public Procurement and Ministry of Finances. No country in Balkan and Europe has such a body ${ }^{4}$. Every institution which desires to buy products must pay to the Council of Public Procurement and then it approves the public procurement. The first legal regulation on Public Procurement in Macedonia was made in 1998, when the first law on public procurement was approved. It was in effect until 2004 when the law on public procurement regulating the main types of procedures was approved.

Also this law had incorporated widely suggestions and recommendation of World Bank. In practice it was noticed that due to the administrative burocracy it resulted as impossible to perform special procurements. The law of public procurements was approved in 2007 and it implementation started to be applied in 2008 and has adjusted the terminology used in the legislation such as "economic operator". "contracting authorities" etc. The law No. 136/2007 on public procurements provides these types of procedures:
a. open procedure
b. limited procedure
c. competitive dialog
d. procedure with negotiation without preliminary announcement of notification
e. procedure with negotiation with preliminary announcement of notification

\footnotetext{
1 Duli, llaz. Public Procurement Reform in Kosovo; Prishtina: 2011; page 23

2 Duli, llaz. Public Procurement Reform in Kosovo; Prishtina: 2011; page 38

${ }^{3}$ Drita Kacandolli -Gjonbalaj, Myrvete Badivuku-Pantina, Procurement phases in the process of procurement in Kosovo, Lex ET Scientia International Journal, nr. 1/2010, page.327.

${ }^{4}$ Aneta Daneva Mostrova, Prokurime publike, JOFI SKEN, Shkup, 2011, page 12.
} 
f. procedure for accumulation of offers with announcement of notification

g. procedure for accumulation of offers without announcement of notification

Despite that Macedonia is still a candidate state and does not have any obligation to transpose in its internal legislation the criteria of the value provided the EU Directives, it has foreseen its criteria of value which in some cases is even more strict. The law on public procurement is applied on every procurement which is over the extent of 500 euro. For the procuration which catch the value 500 to 5.000 Euro, it is applied with the use of the request for accumulation of offers without announcement of notification (8 days) From 5.000 to 20.000 euro (goods and services) and 5.000 to 50.000 Euro with request for accumulation with announcement (14 days). On these edges there are applied open, limited, procedure with negotiation (an announcement), competitive dialog ${ }^{1}$.

The open procedure is a procedure which gives bigger possibility of participation to the bidders. This procedure has some formal aspects applied (short communication in formal manner for the submission of the bid, opening of the bid in public manner etc.) Starting from 2007 there are required at minimum two offers.

The limited procedure is applied in two phases, it is a regular procedure, and usually it is applied for the procurement of goods, works and services where the object of the contract is completed and specific and where the procedure would be prolonged. in order to increase transparency from 2005 it was created the unique register for the publication of the data of entered contracts. This register contains data related to the supplier, bidder, the value of procurements, objects of procurements etc. These data as well as other data are applied in the Official Gazette of the Republic of Macedonia. The procuration procedure has the following stages:

1) Publication or invitation for participation

2) Documentation of tender or preparation of offers

3) opening of offers and assessment of offers

4) realization of contract and surveillance of realization of Contract

Starting from 2004 the Law on Public procurement provides that in case of disagreements between the parties, there is a possibility that they address to the court. In that time the administrative court was not established yet. in 2007 the Law on public procurements provides that for the cases which are not provided explicitly in the law on administrative court the ordinary courts will be competent.

In 2005 The Republic of Macedonia started to use the electronic public procurement with the aid of a project directed by USAID, while the first electronic public procurement was performed in 20006. While the electronic auctions were applied in 2007. In Macedonia it is possible to use the electronic auction only in the criteria of the lowest price. The system through which the electronic procurements are applied is constructed in such a manner that the auction is performed only for the part related to the price. The European Commission in 2000 upon the placement in use of the electronic public procurements is optimist as this procedure creates a new simplified possibility (without any papers and additional expenses- attestation, signatures etc.). Until 2003, the statistics showed that 25 percent from the transactions in the field of public procurement in EU, were applied through electronic means.

\footnotetext{
1 Tiziana Bianchi, Valentina Guidi, The comparative survey on the national public procurement systems across the PPN, Istituto Poligrafico e Zecca dello Stato S.p.A, Rome, 2010, page 131.
} 